\title{
Milestones in Children's Books
}

\author{
B E R N I C E E . L E A R Y
}

It was a very drab and dingy little volume that started me to collecting children's books-not at all the kind of book commonly looked upon as a "collector's item." Or, rather, it was the flyleaf that did it. There, in a cramped Spencerian hand, written in faded violet ink, was the alluring inscription:

TO
DELIA PENDLETON
for
"Fair endeavor to possess
an elegance of mind."
From
HER TEACHER,
E. Sargant
December, 1831

That was all. But there was something about those few words that converted me almost at once to that euphoric state known as bibliomania. Now, after some forty years of searching for early children's books, and the books themselves are housed in The University of Iowa Libraries, the mania still persists.

Book collecting, to anyone but another book collector, is difficult to explain, particularly if it involves "juveniles." To the scoffers who label it a sentimental return to "second childhood," there is little to say but to point out that the return to childhood is, rather, a return to the joys of children, which most of us frequently long for. To your scholarly friends, it is usually best to claim a purely scholarly interest. You have hopes, you say, of compiling a special bibliography of children's books, say about Christmas, as Jacob Blanck has done for boys' books in his Peter Parley to Penrod (R. R. Bowker, 1956). Or, you are interested in the social significance of children's books during some particular period in American history, and you cite F. J. Harvey 
Darton's survey of English social life in his Children's Books in England; Five Centuries of Social Life (Cambridge University Press, 1958).

It is your practical friend who puts you on the defensive. He insists on knowing whether you read all the little old books you buy, or the expensive and beautiful new editions when they are available. Of course, one doesn't always buy a book to read. Everyone knows that. If he wants a book for that purpose, he buys an edition that he can read, and reread, and mark, and lend, and replace, if it is lost or worn out. Kenneth Graham's Wind in the Willows is a good case in point. Who would think of reading the beautiful Arthur Rackham Limited Edition with its handset type and its page designs of curling willow leaves? (The Limited Editions Club, 1940). Especially when the inexpensive E. H. Shepherd Edition with its little pen sketches is available in any public library, and tells the same story? (Scribner, 1933, 1961).

As for buying an expensive book for a collection-well, that's another matter. In the first place, if one wants a book very badly, no price seems high. In the second place, once one has acquired a rare book, why shouldn't he treat it like other rare things-a fine picture or a piece of fine tapestry, to be looked at and not handled? Can't some possessions, even children's books, be justified in the sheer delight they give their owners?

With your fellow hobby-rider, no explanations are necessary. Merely show him your newest "find"-The Life and Perambulations of a Mouse, bound in Dutch paper, and dated 1789; or The Little Merchant with its gay valentine cover, circa 1830; or the 1812 Miniature book enclosed in a locket that you inveigled a reluctant bookseller to part with; or merely point to the personal inscription that set your feet in the book collector's path, and he understands. Whether he be engineer, doctor, or lawyer, and most collectors of early children's books are one of these three, he knows, as you do, that collecting is largely a matter of sentiment, and that there is no sensible justification for what to you is a "delightful diversion" and to others "foolish bibliomania." Unless he's a book-collecting snob, he doesn't care whether a book costs fifty cents or fifty dollars. He knows that so far as you are concerned, it is a rare good thing to own.

Whatever the appeal of early juveniles, their collection provides an interesting background for the books of today's children. In the books of earlier generations are to be found the beginnings of fairy tales and folk tales, moral tales, home and school stories, tales of faraway lands, books of specialized information-all that comprises children's litera- 
ture today. And in them is also revealed the perennial conflict between instruction and entertainment, restraint and freedom, stern and rock-bound realism and gay fantasy, that has been waged with varying degrees of intensity for generations.

The story of children's literature thus obtained is almost as fascinating as the books themselves. But it is a long story, and has been told in considerable detail by a number of writers-Elva S. Smith in The History of Children's Literature (American Library Association, 1937); Cornelia Meigs, et al., in A Critical History of Children's Literature (Macmillan, 1953); and others. All I shall try to do in these few pages is to set up a few milestones that mark the way from the earliest children's books down to the present. My own collection serves as the chief source of reference. To this have been added my own recollections of a reading childhood, substantiated by such bibliographies and catalogs as The Osborne Collection of Early Children's Books, 15661910 (Toronto Public Library, 1958); A. S. W. Rosenbach's Early American Children's Books (Southworth Press, 1933); Andrew W. Tuer's Pages and Pictures from Forgotten Children's Books (Leadenhall Press, 1898-1899); William Targ and Others' Bibliophile in the Nursery, a Bookman's Treasury of Collectors' Lore on Old and Rare Children's Books (World, 1957); and by Leonard DeVries' recent anthology, Little Wide-Awake (World, 1967.)

\section{The First Milestone John Newbery Introduces the Pretty, Little Book 1744-1767}

It is interesting to speculate on the true motive that prompted John Newbery, chemist, pharmacist, genius among book publishers and traders, to turn to the publishing of children's books over 200 years ago. Was it to gain recognition that he set up his little shop "The Bible and the Sun" at the corner of St. Paul's Churchyard in London, and there produced a score or more of gay little books with "flowery and old gilt" covers the like of which no child had ever seen before? Was it his love for children that promoted the publication of Mother Goose's Melody, A Little Pretty Pocket Book, The Renowned History of Giles Gingerbread, A Little Boy Who Lived Upon Learning, The History of Little Goody Two-Shoes, Otherwise Called Margery Meanwell (1745- )? Or The Lilliputian Magazine, of which no monthly issue has been traced, though advertised as such in 1751?

It is a matter of record that although he called himself "the friend of children," he advertised his books for "all his little friends who are good, . . . but those who are naughty are to have none." There seems 
little doubt that these words were intended less as a warning to children than as an assurance to parents that whatever else he might be, he was no instigator of naughtiness.

Was there anything in the idea of revolutionizing children's reading that may have appealed to Newbery"s adventurous nature? Adventurous we know he was. And adventure there must have been in effecting such a compromise in children's books between instruction and amusement that parents would buy them, although they and their parents and their parents' parents had grown up on moral exhortation and morbid concern with death and the Hereafter.

Versatile as he was, Newbery must have read the chapbooks and broadsides that were peddled from door to door even before his time. And he must have deplored the fact that although they were filled with doggerel verse, and condensed, crude, and vulgar stories, they were loved by children, and eagerly bought for "a penny plain, tuppence colored."

He must also have looked back with quite as much dismay at the reactionary publications of the Puritans. He may even have sold reprints of Janeway's Token for Children which was handed down from the Restoration and adapted for New England children by Cotton Mather before its appearance in Massachusetts in 1700. It seems unlikely, too, that he could have escaped The New England Primer, first printed between 1686 and 1690, which enjoyed continuous sales for the next hundred years. Through its miserable little pages the Puritans aimed to promote goodness on earth and joy in the Hereafter as well as to teach children to read.

One important book coming out of the Puritan world must have impressed Newbery in a different way. This was John Bunyan's Pilgrim's Progress (1678), a book for adults, published almost a century before Newbery's time. Underneath its somber theological moralizings was to be found an exciting adventure story that children took to themselves as their own. In the gloomy wanderings of Christian, weighted by his burden of sins, and in the lighter story of Christiana and their sons, Newbery must have noted how children's interests could be reached, even in "a good, Godly book."

He must, also, have felt the appeal of two other books of exciting adventure-Daniel Defoe's The Life and Strange and Surprising Adventures of the Renowned Hero, Robinson Crusoe of York, published in London in 1719; and Jonathan Swift's Gulliver's Travels, available in 1726 when it carried the appended designation Travels into Several Remote Nations of the World. In Four Parts. Neither professed to be a children's book, but both are considered so today, and probably al- 
ways should have been. The popularity of the first was unbelievable. The story swept across Europe like a prairie fire, and before long the name Robinson Crusoe became a magic name to sell any book, however remote from the original story.

To what extent may his hobnobbing with Oliver Goldsmith and Samuel Johnson have led Newbery into children's publications? Again, we can only speculate. For my part, I never think about The History of Little Goody Two-Shoes, which most historians ascribe to Goldsmith, or recall the paltry fee he received from Newbery for bits of hack-work, that I don't fancy I see the two cronies sitting in the back room of "The Bible and the Sun" planning a new book or a new advertising compaign. In all fairness, I should say that I've never checked on the reliability of this image, for were $I$ to discover that there was no "back room" the image would be ruined forever.

By way of exhausting all possible motives, we should probably admit that Newbery's interest in children's books may have been part of his good tradesmanship. Being a man of many business interests, he undoubtedly saw an opportunity to improve his fortunes along with children's books. To him the prospect of producing something drastically different from cheap broadsides and fear-burdened "Tokens" must have looked promising. Be that as it may, the idea of trafficking in books along with medicines was a happy one, for not only Newbery but his successors, as well, enjoyed a prosperous business at "The Bible and the Sun" for many years.

Newbery's most obvious and probably his most important contribution to children's books was that of format. Sending to Holland for Dutch paper, richly embossed in bright colors and gold foil, he soon produced gay, alluring little books that were forerunners of the period which by some is called "The Age of Flowery and Gilt" and by others "The Golden Age in Children's Books"-an age made bright by colorful covers, however dull the contents. Such paper has not been used for more than a hundred years. Yet books with Dutch covers, some of which are in my collection, and uncut sheets of Dutch paper owned by more fortunate collectors, are still bright and shining. Little books, not over four inches high, and many much smaller, bound in bright wallpaper or in plain, pastel paper with valentine covers, proved irresistible. While they may not have made Master Tommy a good boy and Mistress Polly a good girl, they did heighten their love of books and reading, and started the vogue for pretty books.

Newbery's deliberate intention to amuse children through reading was his second contribution. His titles made a direct appeal to children with just enough suggestion of instruction to appease their par- 


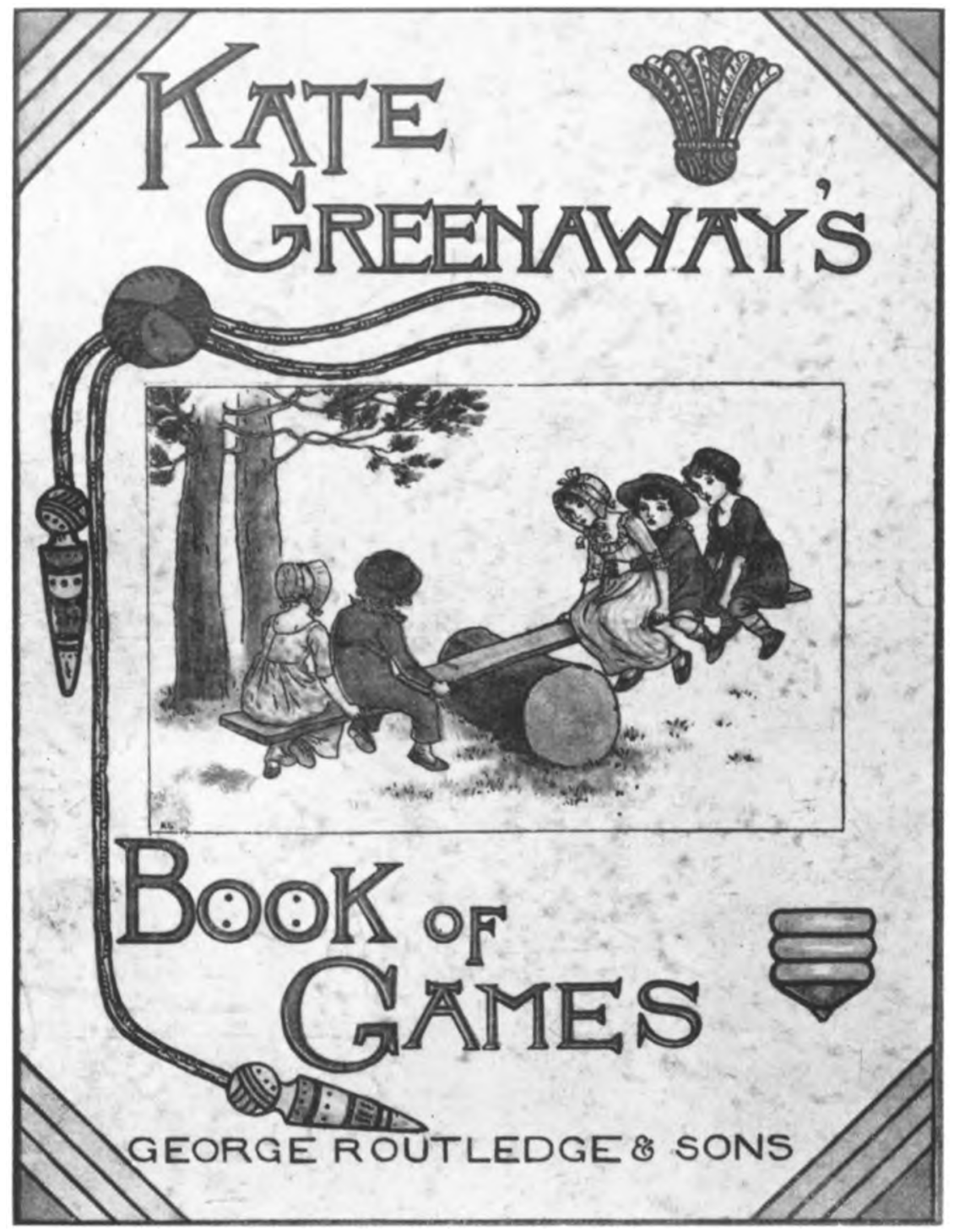

Cover illustration from a Kate Greenaway volume in the Bernice E. Leary gift of children's books. 


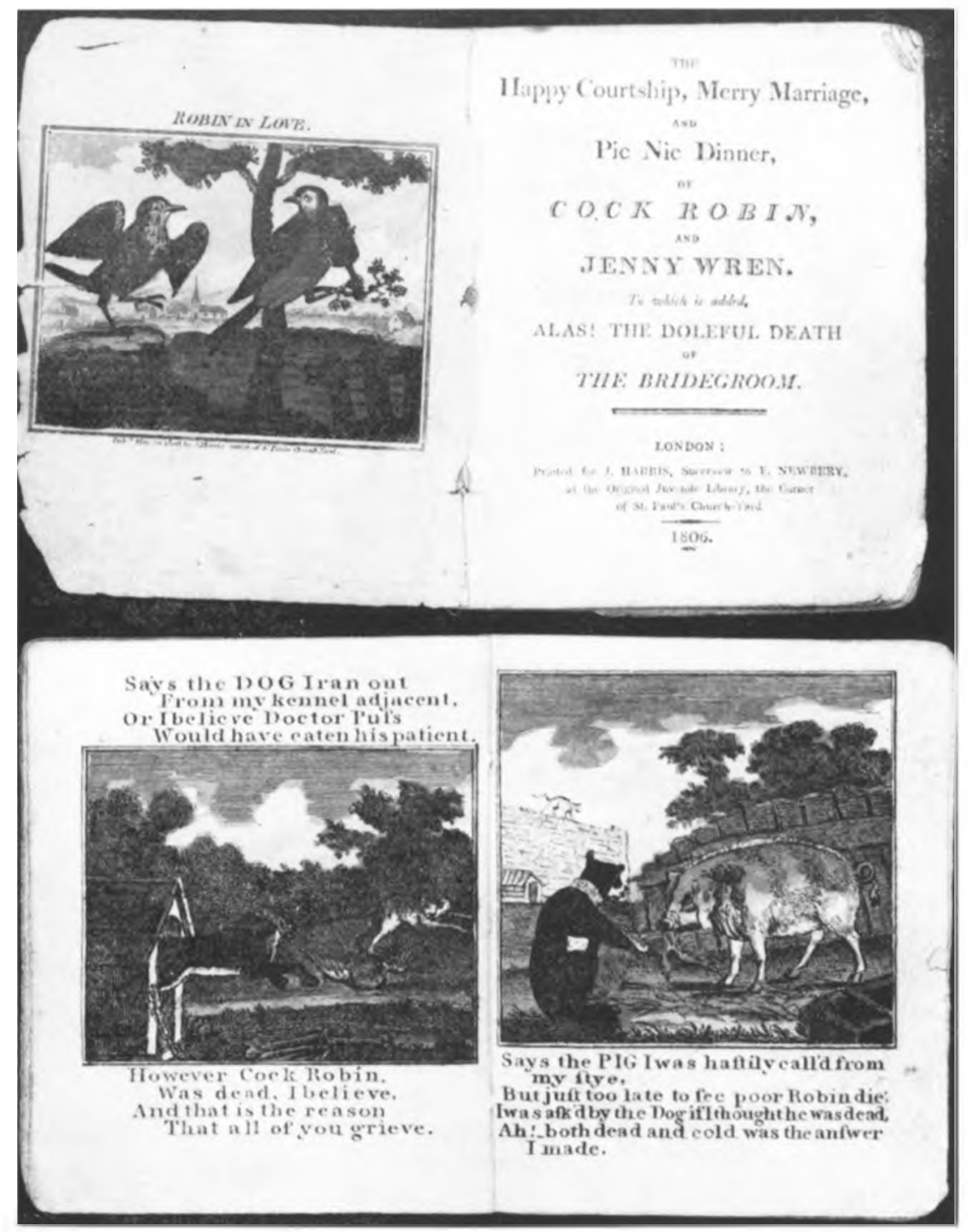

Hand-colored illustrations added their appeal for the youthful readers of these early nineteenth-century books about Cock Robin. Both volumes are from the Bernice E. Leary collection. 
ents. Take, for example, the book A Little Pretty Pocket Book, whose subtitle read:

Intended for the Instruction and Amusement of Little Master Tommy and Pretty Miss Polly, with an Agreeable Letter to read from Jack the Giant Killer, as also a Ball and Pincushion, the use of which will infallibly make Tommy a good Boy, and Polly a good Girl . . . Price of Book alone, $6 \mathrm{~d}$., with a Ball or Pincushion, $8 \mathrm{~d}$.

Compare this with the subtitle of Janeway's Token for Children, which read:

Being an Exact account of the Conversion, Holy and Exemplary Lives and Joyous Deaths of Several Young Children.

Again, note part of the Alphabet Rhyme in Newbery's Little Pretty Pocket Book:

So great $\mathrm{O}$, and $\mathrm{P}$,

Pray what do you see?

A naughty Boy whipt;

But that is not me.

Bad verse though it was, it carried a happier thought than the morbid meditation of the little girl in Janeway's Token:

When by spectators I am told

What beauty doth adom me,

$\mathrm{Or}$ in the glass when I behold

How sweetly God did form me.

Has God such comeliness bestowed

And on me made to dwell

What pity such a pretty maid

As I should go to Hell.

In The History of Goody Tuo-Shoes we find Newbery's third contribution-the original, continuous story that carried the reader through pages of adventures with the child heroine-learning the alphabet, teaching smaller children, burying a pet dormouse, helping the poor, facing charges of witchcraft, growing up, marrying, and dying, "mourned by all who knew her." All this for a mere sixpence. A dull tale, and far from a happy one, but it was a child's story, and the first of its kind, and for that reason deserved to live.

Newbery, too, still lives, though in name only. Each year he is honored when the Newbery Medal is given to the writer of the most distinguished American children's book of the previous year. Frederic Melcher, publisher of Publisher's Weekly, created this award in 
1922, in tribute to the genius and foresight of the English publisher who first believed in children's rights to good books.

\section{The Second Milestone \\ The Moralists Take A Stand \\ 1760-1825}

While Newbery was advancing a happier kind of children's books, the "Guide-to-Heaven School" of the Puritans was developing into a "Didactic School of Manners and Morals." Many of its followers, like Rousseau, would have freed the child from the restraints of civilization altogether, and permitted him to live as a "Child of Nature." And some of them, too, like many of today's educators, were concerned with helping the child to live in "an evolving order," to preserve "the democratic ideal," to develop "well-adjusted personalities," and to learn to "face reality." But the moralists would also hope and expect the child to grow out of an impeccable childhood into an impeccable adulthood.

The most persistent reformers of the Didactic Period were Thomas Day, Letitia Barbauld, Mrs. M. M. Sherwood, Sarah Kirby Trimmer, and Maria Edgeworth. They created a literature marked by simplicity, utility, reason, and realism. Their output was phenomenal, as judged by the reprints still available. In every book, one finds memorable children, chiefly boys, who are incredibly sturdy, hard-working, courteous, courageous, poor, precocious, and prudent. With such sterling qualities, they easily overcame their rude, idle, cowardly, careless, well-to-do adversaries. And from the mouths of "our heroes" fell strings of pure pearls, as in Maria Edgeworth's Illustrated Tales for Children, 1850. "True, I am not hungry now," says Ben, in the story Waste Not, Want Not, "but that is no reason I should never be hungry again." In Dangers of the Street, Edward, the careful boy, observes as he helps the limping George, "Ah, how cautious children ought to be when walking the streets." And Lazy George, brought to justice for thieving and questioned as to what got him into bad company, answers sadly and ungrammatically, "I don't know-except it was idleness."

For moral precocity and priggishness, Thomas Day's little Tommy has no peer. As the curtain falls on his 340-page struggle against human frailties, he is seen for the last time at the mature age of nine, his hair "combed free of powder," "the elegance of his curls demolished," and his dress "divested of every appearance of finery." His face is solemn, his voice is grave as he announces, "Mama, I am now only what I ought to have been. . . . From this time I shall apply my- 
self to the study of nothing but reason and philosophy, and therefore I bid adieu to dress and finery forever." Poor Tommy! Poor Mr. Day! And poor Moralists!

In all fairness, it must be said that the Moralists were generally good story-tellers, though they had little understanding of children. Maria Edgeworth was a notable exception. Born the second child in a family of twenty-two children, she learned early something of child nature, which was manifested in a collection of realistic tales entitled The Parent's Assistant, published in 1804. Of these, Rosamond and the Purple Jar is the favorite, even with today's children. Rosamond, an altogether natural little girl, goes on a shopping trip with her mother, and unfortunately chooses to buy a pretty but useless purple jar instead of much-needed shoes. Later she suffers the natural consequences of humiliation and slovenliness when she is forced to wear her old shoes "until at last she could neither run, dance, jump, nor walk in them." Being a born moralist, she admits her folly. "Oh, Mother," she exclaims, "how I wish I had chosen the shoes! They would have been of so much more use to me than the jar!" But, being also a real little girl, she adds, "However, I am sure-no, not quite sure, but I hope I shall be wiser another time."

Another of Maria Edgeworth's "good" stories is Henry and Lucy, whose main characters so-named are super-children, unbelievably interested in all scientific studies from seashells to bridge building. They do their lessons every day even when on vacation, chiefly because Lucy's mother preaches the doctrine "Never put off till tomorrow what you can do today." Yet, when vacation ends and Lucy reflects on all the pleasures she's had at the seashore, she decides prudishly that "her greatest joy came from the realization that she had done her lessons every day."

The Third Milestone

\section{Toy Books and Adventure Tales Captivate Children} 1806-1830

To the moralists in both England and America who were admonishing their child readers, not only in prose but also in verse, "to behave nicely," the children themselves were turning a deaf ear. Little boys continued to engage in battles, as always, notwithstanding Watt's reminders "Against Quarreling and Fighting" first laid down in Divine Songs, published in 1715:

Let dogs delight to bark and bite,

For God has made them so;

Let bears and lions roar and fight,

For 'tis their nature, too. 
But children, you should never let

Your angry passions rise:

Your little hands were never made

To tear each other's eyes.

And many a not-so-little girl delighted in being a "pert hussy," for all her elders' warnings that

The nymph who walks the public streets

And sets her cap for all she meets,

May catch the fool who turns to stare,

But men of sense avoid the snare.

To these children of the early 1800 s, the appearance of the toy book must have offered a relief. In my collection are three toy books published in 1806 and 1807 by John Harris, successor to Newbery-The Butterfly's Ball, The Elephant's Ball, and Cock Robin. The original covers are gone and the pages show hard wear, but the profuse handtinted illustrations and the printing are still clear. The illustrations were made from copper plates, and the colors put on by small children working together at long tables, each adding his bit of color as the prints were passed along. Sometimes one color is missing from the last pages of an otherwise gay book. Did the small artist fall asleep before his pot of paint? Did he grow tired of daubing blobs of the same color in precise spots? Who knows?

The most charming of these early toy books is Cock Robin (1806), which bears the title:

$$
\begin{gathered}
\text { The } \\
\text { Happy Courtship, Merry Marriage, } \\
\text { and } \\
\text { Picnic Dinner } \\
\text { of } \\
\text { Cock Robin } \\
\text { and } \\
\text { Jennie Wren. } \\
\text { To Which Is Added, } \\
\text { Alas! The Doleful Death } \\
\text { of } \\
\text { The Bridegroom. }
\end{gathered}
$$

And, to which is also added, we may note in passing, some pretty neat advertising for Harris. Not too early, of course, lest it divert interest from the romance. Only when the courtship is culminated in Jennie's consent, and the wedding day has dawned, does a "book" come into the story. Then we are told: 
The Cock he blew his Horn,

To let the Neighbours know,

This was Robin's Wedding-Day,

And they might see the Show.

And first came Parson Rook,

With his Spectacles and Band,

And one of Mother Hubbard's ${ }^{\circ}$ Books

He held within his Hand.

In a finely-printed footnote, Harris showed himself a worthy successor to Newbery by explaining that

-Upwards of ten thousand of this celebrated work have been distributed in various parts of the World in a few Months.

Other toy books, now highly prized as collectors' items, contain stories in rhyme illustrated by colored cut-out figures, separate from the text. A movable head, which may be shifted from one figure to another, completes one picture at a time. Dated 1810, these little books were the joy of Queen Victoria's childhood and that of other children in England and on the continent. One of the most appealing of these books, Ellen, or A Naughty Girl Reclaimed, carries an obviously moral tone, but a happier one than was sounded in the purely didactic book. And happy or not, how could any little girl hear it when busily shifting heads and hats on the paper doll illustrations? Let Ellen be stolen by gypsies because

. . . she is so wayward grown,

Her book upon the ground is thrown.

And kind mama, who loves her well,

Can neither make her read or spell.

Or let her "scream with noise so great/That people heard her at the gate." Let her proud papa "deign not" to forgive her and rescue her from the gypsies. Let the naughty girl be "reclaimed" or not, and let

Both books and work now give delight,

And Ellen learn to read and write.

And, finally, let the story end with the assurance that

Happily now her time she spends,

Loved and esteemed by all her friends.

What did it all matter to the child of 1810 ? Or indeed, what does it all matter to today's collector, if, like myself, he could be the proud possessor of Ellen? Both have been beguiled less by the story than by its "exemplification in a series of movable figures." 


\section{The Fourth Milestone \\ The Brothers Grimm Restore the Fairy Tale 1816-1826}

What with the Puritans and the moralists frowning upon frivolity of any sort, the Nursery Rhyme and Fairy Tale had a hard time of it. Before 1700 Perrault had published his Tales of Mother Goose in French, at a time when both Nursery Rhymes and Fairy Tales were finding their way through the English countryside in the peddler's pack. But neither met with any great enthusiasm among adults. Clockrunning mice, moon-leaping cows, booted cats, wandering goosey ganders, pie-stealing boys, and tart-stealing knaves, along with little men who woo'd little maids, were looked upon by most people as not quite respectable. To the followers of Rousseau, they were symbols of greed, vanity, envy, jealousy, impertinence-"all the worst passions that can enter the human breast."

Then in 1823 came the Grimm Brothers' Household Tales, and German folklore became immediately popular in England. Children loved "Snow White," "The Elves and the Shoemaker," "Rumpelstiltskin," "Hansel and Gretel," "The Bremen Town Musicians" and the other tales as old as the countryside through which the brothers wandered. but always new to children. There was eager anticipation in the indefinite beginning, "Once upon a time," and immense satisfaction in the conclusive ending, "And so they lived happily ever after." What happened in between was of less importance.

As the years went by, and the fairy tale became a part of every child's reading diet, there arose now and then, particularly in England, the old utilitarian clamor against fairies, witches, giants, dwarfs, conjurors, imps, elves, hobgoblins, and other pranksters or magicians. But this was to end for all time, so 'tis said, in the early 1900s with the coming of Peter Pan, who had found the secret of not growing up. James M. Barrie's play, Peter Pan, made its first appearance on the stage December 27, 1904. Night after night, Peter Pan filled the playhouses. The young lived its every word, and followed breathlessly Peter Pan's adventures in Never Never Land. The old forgot that they were old, and their souls gradually became childlike, until at the end of the play they unconsciously admitted the reality of fairyland. Here, you remember, Peter Pan moved downstage, and in an effort to save Tinker Bell, stretched his hands across the footlights and made his impassioned plea for faith in fairies, "Tell me you believe in fairies. Say that you do." Those who were young made no reply. Their faith was understood. But those who were old fumbled in their pockets for a handkerchief, as they answered in one voice, "We dol" At last the 
battle against fairy stories was ended. At least, so it is said. From now on, young readers might devour The Blue Fairy Book, The Red Fairy Book, The Yellow Fairy Book, The Purple Fairy Book, and all the rest of Andrew Lang's "coloured" fairy books (1889-1906), with no fear of parental interference.

Whatever the fairies in these early books lacked in convincingness was made up a hundred years later in the poetry of Rose Fyleman. In her Fairy Friends (1926) and Fairies and Chimneys (1920), she makes fairies seem familiar everyday companions. For doesn't she see them often in the bottom of her garden-dancing in the rain, drying their wings in the sun, playing in the fountain, hanging fairy washings out among the clover, dashing behind a cloud to tidy up their hair? And once, didn't she see a fairy riding on a bus in Oxford Street!

$$
\begin{aligned}
& \text { And oh! my dears, just think of it, just think } \\
& \text { what luck for me, } \\
& \text { That she should come to Oxford Street, and } I \text { be } \\
& \text { there to see! }
\end{aligned}
$$

The Fifth Milestone

Children Go Places and See Things

1825-1835

The restoration of the fairy tale in England only slightly antedated America's first major contribution to children's literature through a "Learn-Something-Every-Day" School of writers. Tales of Peter Parley, Peter Parley's Visit to London, Peter Parley's Tales About Asia, Peter Parley's Tales About America-these and more than 100 other books were written by Samuel Goodrich or "Peter Parley," between 1827 and 1830, with "the view of imparting knowledge of a useful kind."

The "knowledge imparted" was a kind of simplified history, geography, science, and travel, written in a straightforward, not unpleasant, style that set a pattern still followed in many informational books. It is used, for example, in the All About Books and The Landmark Books published by Random House since 1950, that give children good, sound information about people, places, and things.

A somewhat different pattern of informational book was initiated by Goodrich's contemporary, the Reverend Jacob Abbott, a Congregational minister. Rallying to the watchword "Fidelity to Fact through Story," he launched a series of travel stories (1834-1858) that took Rollo, his hero, on a kind of personally-conducted tour through city after city and country after country. His pace was slackened only for an occasional travel talk or sermon on morals. The details 
now seem tedious, the descriptions interminable, and the tone patronizing, but these are less important to the average child than the fact that Rollo in Rome, Rollo in Paris, Rollo in the Alps is going places and seeing things and talking about his adventures afterwards. And few characters in children's books go and see and talk as much as Reverend Abbott's.

\section{The Sixth Milestone \\ English and American Writers Give to the World \\ "A Number of Things" \\ 1840-1900}

More than a hundred years had now passed since John Newbery started a revolution in children's books, and the child's world was ready for "a number of things." As the demand for books grew, writers became more individualistic. They were less fearful, less provincial, better educated, and more experienced in writing. It is not surprising that their books have lived and become such a part of our lives that they seem to have been here always.

A white rabbit with a watch in his waistcoat pocket and a glove in his hand-hasn't he always scurried through the woods murmuring "Oh, my ears and whiskers! I shall be late for the Duchess' Garden Party"? And hasn't there always been a Mad Hatter, a madder March Hare, and a drowsing Dormouse, asking riddles without answers, making rhymes with no sense, telling time that is always six o'clock, and speculating on "the much of a muchness"? Not until a shy, learned scholar, Charles Dodgson, turned entertainer of children, and as Lewis Carroll created Alice's Adventures in Wonderland (1865).

And hasn't there always been Tom-"dogged, hard, gnarly, foursquare brick of an English boy, that . . . never turned his head once all the way from Peacepool to the Other-End-of-Nowhere," that loved lollipops, that chased Water Babies in water and was himself chased on land? Not before Charles Kingsley wrote The Water Babies; A Fairy Tale for a Land Baby in 1863, and gave it to his son along with the now immortal poems, "I once had a sweet little doll, dears," and "When all the world is young, lad." And that was about the time of Alice.

What of little Diamond to whom the Apostles talked in church, who was called "God's Baby" by the "cabbies" on the stand, and who, so his playmates said, "wasn't all right in the head, you know-a tile loose"? A Diamond who by day supported the family by driving his father's cab (in true Thomas Day fashion), but who at night left his weariness, his ugly stable life, and the neighborhood brawls to go At 
the Back of the North Wind? And there to be rocked in the nest of North Wind's long hair while she swept cobwebs from the sky? Can it be that he is younger than Alice? And that he was created by Lewis Carroll's friend, George MacDonald, in 1871, as much to improve the young mind as to leave it fancy free? We can't contradict fact. Yet to many of us, Diamond is as ageless and eternal as the moon that lighted his loft bedroom, and his story as intangible and elusive as North Wind herself.

Haven't we always had "A Brave Tin Soldier," a lily-leaf "Thumbelina," a story-telling "Snow Queen," an "Ugly Duckling" that turned into a swan, a "Little Match Girl" glimpsing eternal life on New Year's Eve? Was it only in 1846 that Hans Christian Andersen created his fanciful world where tops, coins, money bags, bottle necks, frayed shirt collars, darning needles, gardener's tools, shadows, matches, tin soldiers, china ornaments-all things that caught his eye-were embodied with souls, and made to live and love and die as mortals? And is it only since Andersen's time that other writers have felt the reality of other-worldness and been free to people it with rag dolls, teddy bears, toy horses, dollar watches, velveteen rabbits, sky scrapers, broken-down engines, willow whistles, each to play a dramatic human role? How fortunate that The Rootabaga Pigeons (1923), The Wonderful Wizard of Oz (1900), Mary Poppins (1934), Dr. Doolittle (1922), The Hobbit (1938), and their kin, should have found an Andersen-made world waiting for them!

Or was it Edward Lear's nonsense world that awaited them? His was a world of absurdity in which an Owl and a Pussy Cat could go to sea in a beautiful pea-green boat and return a happily married couple, and where Jumblies could go to sea in a sieve, and "all came back in twenty years, or more." Lear's made-up words, some of which now hold a place in the dictionary, his "melobious" metres, as he labelled them, and his ridiculously-compressed stories were altogether new in 1846. Indeed, they were as "far and few, far and few," as "the lands where the Jumblies lived." And they were as hilariously funny to Lear himself as they were to his readers. Something of his charm and spontaneity and nonsense has been carried on by later writers-Laura E. Richards (Tirra-Lirra, 1932), A. A. Milne (When We Were Very Young, 1924), and others.

What of Stevenson and his Treasure Island, with its immortal Jim Hawkins and the crew of the Hispaniola, its villainous Long John Silver and his band of pirates? Has he been holding his readers spellbound only since 1886? Originally written for a school boy who wanted "something craggy to break his mind upon," Treasure lsland 
has already given generations of readers not only "something craggy" but also romance, mystery, and breath-taking adventure.

A less memorable book, but one that made its contribution to children's literature, was Thomas Hughes' Tom Brown's School Days (1857), published under the pseudonym "An Old Boy." Here for the first time the characters were really human beings, with different personalities, each acting from his own nature. To be sure, the time is a bit remote from today's children and the English public school a different institution from the American public school, but the story still "goes over," with a little skipping and skimming. A good sports story, which this book really is, can always claim readers.

As for Christmas stories, how many Scrooges since Dickens' time have cried, "Spiritl Hear me! I am not the man I was!" And how many have held up trembling hands to the pledge, "I will honor Christmas in my heart and try to keep it all the year?" The number is large in Christmas books, yet all had their beginnings in the miracle of Dickens' Christmas Carol. And that was in 1843.

While the Mid-Victorian writers in England were thus trying to compensate for the prosiness of their predecessors, American writers were working equally hard in several different directions. Still realists, they were giving children more vivid pictures of faraway lands, as in Mary Mapes Dodge's Hans Brinker or the Silver Skates (1866); Mrs. Johanna Spyri's Heidi (1854); stories of happy, respectable family life, like Little Women (1868), though let me say here, that no child-boy or girl-has ever forgiven Louisa Mae Alcott for allowing lovable, impetuous Jo to marry stuffy Professor Baer.

Among other family stories were the so-called girls' stories that had their beginning with Martha Finley's Elsie Dinsmore (1867), that carried the heroine through a long lifetime until her triumph as a grandmother, still pure, still pious, and still wringing tears from the eyes of her little girl readers who always thought Elsie "too good to be true," as indeed she was.

Truer girls followed Elsie, as in The Katy Did Series by Susan Coolidge (1873-1874), The Little Colonel Books by Annie Fellows Johnston (1896-1907), recently revived by Random House (1959), and Sophie May's seven-volume Dotty Dimple Series (1865-1897), in which Dotty, a torment to her parents and a recognized "holy terror," lived through continuous cycles of misdemeanor and repentance. These and other series books have always been a great joy to little girls for whom the closing of one book meant the opening of another, and the more books left to be opened, the greater the joy.

Among other girls' books that will always be cherished in the hearts 
of their readers are those by Kate Douglas Wiggin, who was loved along with her books, particularly The Birds' Christmas Carol (1887), a sweet, tearfully-humorous story; and Rebecca of Sunnybrook Farm (1903), the story of a real, live, altogether unstereotyped little New England girl.

For all that girls' books appeared in great numbers during this period, boy readers were not neglected. They were given generous doses of success administered through Horatio Alger, Jr.'s Bound to Rise, Paul the Peddler, Slow and Sure (1872-1873), and other incredible stories. To satisfy boys' love for adventure and excitement, there were happily more believable stories-Rudyard Kipling's Captains Courageous (1897), James O. Kaler's Toby Tyler, or Ten Weeks with a Circus (1881), Thomas Bailey Aldrich's The Story of a Bad Boy (1870), and Samuel L. Clemens' The Adventures of Tom Sawyer (1876), and The Adventures of Huckleberry Finn (1885), whose heroes were the first natural, unrepressed, unrefined characters in boys' fiction.

For both girls and boys there appeared late in the 1800s a new lot of nature and animal books that all children took to their hearts immediately. Their interest has never waned, though later books have been more scientific than they were in 1889 when Merry Little Breezes frolicked across the Green Meadow in Thornton Burgess's Stories Mother Nature Told Her Children. And less sentimental than when Anna Sewell wrote Black Beauty (1891), and Marshall Saunders followed with Beautiful Joe (1894), though both books were immensely popular, and are still read.

Among the good reliable nature books published about this time were Ernest Thompson Seton's Wild Animals I Have Known (1898), Anna B. Comstock's Ways of the Six-Footed (1903), and John Burrough's Squirrels and Other Fur-Bearers (1900). All were forerunners of the tremendous number of fine nature books produced today.

In both England and America, a few writers were telling stories of heroism from Greek Mythology for Mid-Victorian children, but ended up by telling them for later generations as well. Nathaniel Hawthorne's Wonder Book for Girls and Boys (1852), James Baldwin's Story of Siegfried (1882), and Charles Kingsley's Heroes (1855), followed years later by Padraic Colum's Golden Fleece, and the Heroes Who Lived after Achilles (1921), contain not only the finest stories of heroism but also the best background for many literary masterpieces.

These are but a few of the books that formed the Great Continental Divide in children's literature. On the one side lay the old workedover, worn-out land of the traditionalists, and on the other, stretched a 
fresh, green country where experimenters and dreamers could find freedom.

\section{The Seventh Milestone \\ "And So They Lived Happily Ever After" 1900-1970}

By 1900 , the course was well-charted for fanciful tales and realistic stories of all kinds. In whatever direction the children's writer now might choose to go, his way lay open and free. That he has chosen to go in many directions since that time is shown by the great variety of children's books published in the last seventy years, and by the great number, about 2,300 , now published annually.

There are books available for every need, from lesson-learning to pillow-smoothing. Big books, little books, middle-sized books, they deal with animals and architecture, pioneers and presidents, stars and stagecoaches and spaceships; with hobbies-stamps, puppets, coins, photography, camping; with making things-kites, canoes, valentines, willow whistles, tree houses; with going places, to almost every spot on the globe, by bus, train, clipper ship, or jet; with all the things that the child thinks about, dreams of, and wishes for. In the realm of fantasy, the new books go beyond fairyland, as such, and range from the mysterious and supernatural, through the grotesque and incongruous, to pure, aimless nonsense.

If they carry more appeal than earlier books, and most of them do. it is partly because their writers have a greater understanding of children, and partly because they are closer to modern living. Zooming to Mars by rocket ship with Miss Pickerell in Ellen MacGregor's Miss Pickerell Goes to Mars (1951), or sharing a wonderful flight to the Mushroom Planet, is infinitely more alluring to the space-enamored ten-year-old of 1970 than following Alice down a rabbit hole. And he arrives in Wonderland either way.

Similarly, Black Beauty (1891), although it still holds a place in children's affections, seems pretty old-fashioned and made-to-order beside Will James' Smoky, the Cowhorse (1921), and Marguerite Henry's King of the Wind (1948), books that will some day join the rank of the "classics."

Poetry has shown perhaps the greatest change. The old messagebearing, moralizing quality is gone, as are the pretty, but often forced rhyme and rhythm. In their place is the everyday enchantment of living. A few of today's writers are showing this enchantment in poetry about how a child feels, sees, thinks, and does. It is as direct as prose, as simple as a child's own speech, and as real as living. In Harry Behn's The Golden Hive (1966), winds whistle long and loud, 
and a train bell sounds through the night air, more sharply than child has ever noticed before. Again, in What Is That Sound? (1966), the author, Mary L. O'Neill, tries to put sounds in verbal terms, often onomatopoeic; as "A buzz is bee-talk-/. The zzzz of the gnaw/ of a thing being cut/ with a circular saw."

John Ciardi, in his narrative poem The King Who Saved Himself from Being Saved (1965), delights children with his spoofing of a peaceful king in a peaceful country, and a roaring hero who would upset all the peacefulness were he not regretfully killed by the King's bullet.

There are many Haiku translations in today's poetry such as those by Sylvia Cassedy (1967). The Haiku shows children how the bare content of a poem is revealed through images of sight and sound, making them eager to try their hand at similar writing.

Seventy years is a long way to go without specific milestones. But milestones seem unimportant when one travels along a "freeway." Influences there have been in these seventy years-the addition of children's book editors in publishing houses, reviews of children's books in general magazines, the expansion of children's libraries, the Newbery Award for distinguished literature (1922), and the Caldecott Award for distinguished illustrations (1938). The growing respect for writers of children's books, and the growing desire of general writers to write for a child audience have also had their influence.

Many of the books published since 1900 arouse in some of us treasured memories of our own childhood. Wind in the Willows (1913), The Tale of Peter Rabbit (1903), Mrs. Wiggs of the Cabbage Patch (1901), The Just So Stories (1902), Understood Betsy (1917), Jim Davis (1912), Penrod (1914)-these are but a few of "the Great Companions" that are still young in the history of children's literature. Were we to make a systematic search of our reading memories, each of us would add other, less-known titles, important only to ourselves. They are the books we can look back upon and continue to enjoy all our lives.

Books of later date, even of 1970, are already opening up new worlds for children-worlds so satisfying that, in their turn, they too may live forever. 